\title{
PRODUCTIVITY OF HAIRY WATER LILY (Nhymphaea pubescens Will.) SEEDS IN SOUTH KALIMANTAN'S BACKSWAMPS BASED ON LINEAR MODEL
}

\author{
Rusmayadi ${ }^{1}, G$ and Khairina, $R^{2}$ \\ Research Center of Lambung Mangkurat University \\ Jl. Brigjen H. Hasan Basry Kalimantan Selatan (70714) \\ 1e-mail: gustirusmayadi@yahoo.co.id
}

\begin{abstract}
The study on the productivity of water lily seeds in South Kalimantan's backswamps using Wageningen method and the interview with middle traders could give more information about water lily as food commodity. Rainfall pattern in Tabalong, Hulu Sungai Utara (HSU) and Hulu Sungai Selatan (HSS) regencies is like $U$ letter. $U$ type is sensitive with Monsoon. This Monsoon area is affected by easterly wind and local wind. When the sun is at the south side in October to March, the Monsoon moves from west to south east, and in the other way around in April to September, the wind moves from south east to west. In April, the height of water level in some different areas was the same. The highest water level was in Paharangan subdistrict that could reach more than $100 \mathrm{~cm}$ and the lowest was in Hambuku subdistrict, about $80 \mathrm{~cm}$. Based on the interview with middle traders, it was found out that in Hambuku subdistrict and its surrounding area, there was about 1.0 to 1.7 t/ha of water lily seeds each period. In Ampukung, Hambuku and Paharangan subdistricts, the water lily seeds were about $1.121 \mathrm{t} / \mathrm{ha}, 1.057 \mathrm{t} / \mathrm{ha}$ and $0.653 \mathrm{t} / \mathrm{ha}$, respectively. If the paddy fields in Tabalong, HSU and HST regencies are 10,683 ha, 21,2252 ha, and 18,763 ha, respectively, those areas potentially can yield about $11,976.661$ t/ha, 224,456.2 t/ha and $12,254.6778 \mathrm{t} / \mathrm{ha}$. Whereas, based on radiation $(\mathrm{Rg})$, the photosynthetically active radiation on very clear days $(A c)$, in cal $\mathrm{cm}-2$ day -1 , and daily gross photosynthesis rate of crop canopies on very clear days (bc) in $\mathrm{kg}$ ha- 1 day- 1 for $\mathrm{Pm}=20 \mathrm{~kg} \mathrm{CH} 2 \mathrm{O}$ ha- $1 \mathrm{hr}-1$, it showed that the yield of hairy water lily seeds in Ampukung, Hambuku and Paharangan subdistricts was $1.1560 \mathrm{t} / \mathrm{ha}, 1.1425 \mathrm{t} / \mathrm{ha}$ and $1.1021 \mathrm{t} / \mathrm{ha}$, respectively. Hairy water lily naturally grows with seeds in soil and water in paddy field, so it can grow, develop, and produce seeds. Therefore, agronomical technique is important for further study.
\end{abstract}

Keywords: hairy water lily, Wageningen, yield potential.

\section{INTRODUCTION}

South Kalimantan has swamp areas of about 800,000 ha, but only about 390,240 ha $(48.78 \%)$ has been utilized for paddy field. Half of those areas, about 55,125.5 ha $(0.67 \%)$, is in Hulu Sungai Utara Regency and only about $34,445.0$ ha is used for paddy field (BPS, 2010).

Generally, South Kalimantan swamps can be categorized into three types, namely tidal swamp, monotonous swamp and backswamp. The types of swamps in Hulu Sungai Utara Regency is backswamp and monotonous swamp where many waterplants like hairy water lily can grow. According to Fuaddi (1966) hairy water lily is abundant in Hulu Sungai Utara Regency, mainly at Alabio polder area. Hairy water lily is also abundant in Danau Panggang and its surrounding area.

The swamps in South Kalimantan are suitable for hairy water lily because water lily is best grown in the area with the temperatures of $200 \mathrm{C}-30 \mathrm{oC}$ (Stodola, 1987). When the swamp is filled with water, some of fish start spawning and some of other water plants also grow, such as water spinach (Ipoemea aquatica), water hyacinth (Eichornia crassipes), lotus (Lotus $\mathrm{sp}$ ) dan water lily (Nymphaea pubescens Wild.).

Hairy water lily (Nymphaea pubescens Wild.) is known by the community around the swamp as the source of food. The parts of the plant that can be used as the sources of food are seed, tuber and flower. Usually this crop is abundant around Panggang and Bangkau lakes.

The hairy water lily is an aquatic plant having erect perennial rhizomes or rootstocks that anchor it to the mud in the bottom. The rhizomes produce slender 
stolons. Its leave blades are round above the water and heart-shaped below 15-26 (-50) $\mathrm{cm}$, papery, abaxially densely pubescent. Some of the leaves that emerge rise slightly above the water held by their stem in lotus fashion, but most of them just float on the surface. The floating leaves have undy edges that make a crenellate effect.

The hairy water lily is also commercialized as an aquarium plant. The underwater leaves of this species have a handsome appearance that is appreciated by aquarists who often remove the floating leaves to keep it as a fully subaquatic plant. The flowers are quite large, about $15 \mathrm{~cm}$ in diameter when fully open. They tend to close during the daytime and open wide at night.

Hairy water lily has tuber and strength root up to $1 \mathrm{~m}$ long. The leaves of hairy water lily float up to water. The leaves are dark green upside, but red-violet downside. The leaf is egg-shaped about $4-12 \mathrm{~cm}$ in diameter and the leaf side is folded. The leaf also has petiole (Stodola, 1987).

The hairy water lily can flower saveral times in a year. The flowers arise up to water and blossom at around 18.00-19.00 pm, and then it is closed tomorrow morning before midday. The flower will make a round fruit with a diameter of about $4-12 \mathrm{~cm}$. The seeds are brown-black in colour, which are stored in the fruit. They have pericarps so they can be separated from fruit. The seeds can be cooked like rice. It has astringent and brown colour.

In Philippines and Indian, hairy water lily seeds can be made as bread flour (Sastrapradja \& Bimantoro, 1981). Fuaddi (1996) said that the hairy water lily seeds contain carbohidrate at about $78.13 \%$.

The maximum yield can be predicted based on the climatic conditions during the crop growth, the amount of radiation that can be received and the crop capacity to convert energy to photosintat and to distribute it to the crop organ. The length of the crop growth until the crop can be harvested will be determined by the total radiation received, which can determine the crop yield.

If the availability of water is enough for the crop requirement, the crop yield will be determined by nutrition and pest and desease. Therefore, crops will give the maximum yield $(\mathrm{Ym})$ depending on the environmental conditions. In this case, the maximum yield $(\mathrm{Ym})$ will be determined by genetic potential and crop's capability to adapt with climatic condition.

The climatic factors that can effect the crop growth and the yield are temperature and intercepted radition. Generally, temperature determines the crop development and effect the rate of crop development and the crop growth periods. The corn for example, at temperature of 25$30^{\circ} \mathrm{C}$ can be harvested in 100 days. However, at a temperature of $20^{\circ} \mathrm{C}$ it can be harvested in 150 days and even more than 250 days if the temperature reaches $15^{\circ} \mathrm{C}$ (Doorenboss \& Kassam, 1988).

Photosynthesis produces the source of assimilates which plants use for growth. The rate of photosynthesis is influenced by both radiation and temperature, but plants also have an obigatory development pattern in time and space, which must be met if the photosyntetic assimalates are to be converted into economically useful yields of satisfatory quantity and quality (FAO, 1978). The development sequence of crop growth in relation to the crop phenelogy is influenced by climatic factors, particularly the temperature and day length. In general, temperature determines the rate of growth and development. In some cases, temperature may determine whether a particular development process will begin or not. Low temperature can cause problems through delay in flowering and fruit setting. On the other hand, low night temperature during the ripening period will favour saturation and can lead to high yields. The day-length plays an important role in determining the time of flowering of photoperiodic sensitive crops. A good example is a deep water rice, which will only flower after the dark period has exceeded a specific length. Therefore, the temperature regime and the photoperiodic regime during a certain length of growing period govern the selection of the crop to be cultivated. When the climatic phenological requirements are met, both temperature and radiation set a limit to crop prduction or, in other words, determine the potential net biomass production.

Information about hairy water lily seeds is needed to develop its potentioal as food comodity from wetland. Therefore, the estimation of hairy water lily seeds with linier model like agro-ecological zone (AEZ) is needed to figure out how many seeds are available as the food commodity. 


\section{MATERIALS AND METHODS}

\section{Methods}

The net biomass production $\left(B_{n}\right)$ is different from gross biomass production $\left(B_{g}\right)$ and respiration loss $(\mathrm{R})$ :

$$
B_{n}=B_{g}-R
$$

The rate of net biomass production $\left(b_{n}\right)$ is similarly related to the rate of gross biomass production $\left(b_{g}\right)$ and the rate of respiration $(r)$ :

$$
b_{n}=b_{g}-r
$$

The maximum rate of net biomass production $\left(b_{n m}\right)$ is reached when the crop fully covers the ground surface. If the growth per unit time is plotted againt time, the resulting curve has the shape of a normal distribution curve. It is assumed here that seasonal average rate of net biomass production $\left(b_{n a}\right)$ is half the maximum crop growth rate $\left(0.5 b_{n m}\right)$. This means that net biomass production for crop of $\mathrm{N}$ days is:

$$
B_{n}=0.5 b_{n m} \times N
$$

In order to calculate $b_{n m}$ we need to know the maximum rate of gross biomass production $\left(b_{g m}\right)$ and the respiration rate, $r_{m}$. Hairy water lily is C3 species that operates optimally at temperatures of $25-30^{\circ} \mathrm{C}$.

De Wit (1965) has calculated the amount of photosynthetically active radiation (PAR) on perfectly clear days at different latitude for each month of the year $\left(A_{c}\right)$. On a totally overcast day $P A R=0.2 A_{c}$. If we also assume that PAR $=0.5 R_{g}\left(R_{g}=\right.$ total short wave radiation), the fraction $(\mathrm{F})$ of the daytime when the sky is overcast is then decribed as:

$$
F=\left(A_{c}-0.5 R_{g}\right) / 0.8 A_{c}
$$

De Wit (1965) has also calculated the maximum rate of gross biomass production by a crop when the leaf index (LAl) equals 5 , on perfectly clear days $\left(b_{c}\right)$ and on totally overcast days $\left(b_{0}\right)$, given that $P_{m}$ (the maximum rate of leaf photosynthesis at light saturation is $20 \mathrm{~kg} \mathrm{CH}_{2} \mathrm{O} \mathrm{ha}^{-1} \mathrm{hr}^{-1}$. The values for $A_{c}, b_{c}$ and $b_{0}$ are given in Appendix II, Table 1 (FAO, 1979). It is now possible to calculate the actual rate of maximum gross biomass production $\left(\mathrm{b}_{\mathrm{gm}}\right)$ :

$$
b_{g m}=F x b_{0}+(1-F) x b_{c}
$$

We have seen that the maximum rate of $\mathrm{CO}_{2}$ exchange $\left(P_{m}\right)$ depends both on temperature and the photosynthetic pathway of the crop species. Based on Figure Relationships between maximum leaf photosynthesis rate and the temperature for crop groups I, II, III, and IV (FAO, 1979), the value of $P_{m}$ can be found if the actual daytime temperature and the crop adaptability group is known. If $P_{m}$ is more than $20 \mathrm{~kg}$ $\mathrm{CH}_{2} \mathrm{O} \mathrm{ha}^{-1} \mathrm{hr}^{-1}$, the the value of bgm from equation should be increased; if $\mathrm{P}_{\mathrm{m}}$ is less than $20 \mathrm{~kg} \mathrm{CH}_{2} \mathrm{O} \mathrm{ha}^{-1} \mathrm{hr}^{-1}$ then bm should be decreased. The amount of increase and decrease respectively are given by then following formulas:

$b_{g m}{ }^{+}=0.005 y \times F \times b_{0}+0.002 \times y \times(1-F) \times b c$ $b_{g m}{ }^{-}=0.005 y \times F \times b_{0}+0.001 \times y \times(1-F) \times b c$ In which $\mathrm{y}=y=\left(\left(P_{m}-20\right) / 20\right)$ If $\mathrm{P}_{\mathrm{m}}$ is greater then $20 \mathrm{~kg} \mathrm{CH} \mathrm{CH}_{2} \mathrm{O} \mathrm{har}^{-1} \mathrm{hr}^{-1}$, and $\mathrm{LAl}=5$

$$
\begin{aligned}
b_{g m}{ }^{+}=F \times b_{0}(1+ & \left.0.025\left(P_{m}-20\right)\right) \\
& +b c\left(1+0.01\left(P_{m}-20\right)\right)
\end{aligned}
$$

If $P_{m}$ is less than $20 \mathrm{~kg} \mathrm{CH}_{2} \mathrm{O} \mathrm{ha}{ }^{-1} \mathrm{hr}^{-1}$, and $\mathrm{LAI}=5$

$$
\begin{aligned}
b_{g m}{ }^{-}=F \times b_{0}(1+ & \left.0.025\left(20-P_{m}\right)\right) \\
& +b c\left(1+0.01\left(20-P_{m}\right)\right)
\end{aligned}
$$

The following relationship has been established to calculate $r_{m}$ :

$$
r_{m}=k b_{g m}+c B_{m}
$$

In which $k=0.28$, independent of crop species and temperature,

$$
c_{t}=c_{30}\left(0.004+0.0019 T_{\text {mean }}{ }^{2}\right)
$$

It was found that the maintenance respiration constant "c" was dependent on both crop species and mean temperature. At $30^{\circ} \mathrm{C}$ for non-legume is 0.0108 .

The cumulative net biomass $\left(B_{m}\right)$ is equivalent to half the net biomass at the point of inflexion, then $B_{m}=0.5 B_{n}$. The net biomass for a crop of $\mathrm{N}$ days is:

Then,

$$
B_{m}=0.25 b_{n m} \times N
$$

So,

$$
\begin{array}{r}
b_{n m}=b_{g m}-\left(k b_{g m}+c_{t} B_{m}\right) \text { or } b_{n m} \\
=0.78 b_{g m}-c_{t} B_{m}
\end{array}
$$

$$
b_{n m}=0.78 b_{g m} /\left(1+0.25 c_{t} N\right)
$$

The final equation is needed to calculate the net biomass production, given that LAl at the time of maximum gross biomass production rate is 5 , then read as follows:

$$
B_{n}=0.36 b_{g m} /\left(N^{-1}+0.25 c_{t}\right)
$$

In order to calculate the net biomass production of the actual maximum LAI, the result should be multiplied by the reduction factor $R_{\mathrm{LAl}}$ : 


$$
B_{n(\text { actual } L A I)}=R_{L A I} x B_{n(L A I=5)}
$$

The yield biomass $\left(B_{y}\right)$ can be calculated if the harvest index $(\mathrm{Hi})$ is known, which is the fraction of the net biomass of the crop that is economically useful:

\section{Materials}

The tools used in the study were scale, meter/gauge and office tools.

\section{Site and Time Research}

The study was conducted in three regencies that have backswamps, namely Tabalong (Kelua subdistrict), Hulu Sungai Utara (Sungai Pandai subdistrict) and Hulu Sungai Selatan (Daha Utara subdistrict).

Sample plot was made to get primer data. The sample plot area was a wet rice field of 1 hectare dominated by hairy water lily. The width of plot was 1 hectar divided into 10 of $10 \mathrm{~m}^{2}$ small plot. From each plot, 5 sample crops were taken.

The seed production per clump was observed every week for 10 weeks. The environment parameter was the sea water level, and some growth parameters were length of crop $(\mathrm{cm})$, total leaf per clump (leave), total flower per clump (item), total fruit per clump (item), total harvested fruit per clump (item), seed weight (g) and seed weight per crop (g).

\section{RESULTS AND DISCUSSION}

\section{Hairy water lily's Environment}

\subsection{Climate}

The climate in thestudy areas was presented in Table 1,2 and 3 . The rainfall pattern in Tabalong, HSU and HSS regencies have $U$ shape. That type is very sensitive be affected by Monsoon wind. Those areas are very affected by easterly passat wind and southeast passat wind, as well as local wind. If the sun in south from equator in October to March, Monsoon wind

$$
B_{y}=H_{i} x B_{n}
$$

For the validation of the yield biomass $\left(B_{y}\right)$ we made a plot of $10 \times 10 \mathrm{~m}^{2}$ in width.

moves from western to southeast. On the contrary, in April to September, the wind will move from southest to western.

Ampukung area has A climate type with $Q$ value $=10.2 \%$ or this area is very wet with tropical rainforest according Schmidth Ferguson (1951) classification and has C1 climate type according to Oldeman (1980) classification system or in one year paddy in this area can be cultivated one time and two times, crops planted as $2 \mathrm{~d}$ crop in dry season. The annual rainfall is about 2,527.2 $\mathrm{mm}$ and evapotranpiration $1,354.4 \mathrm{~mm}$ or $3.71 \mathrm{~mm} /$ day.

Hambuku area has $C$ climate type with $Q$ value $=52.9 \%$ or approximately wet with a rainforest that has vegetation with leaf down at dry season according to SchmidthFerguson (1951) classification and has C2 climate type according to Oldeman (1980) classification system or in one year this area can cultivate paddy one time and crops planted as $2 \mathrm{~d}$ crop in dry season must be planted carefully. The annual rainfall is about 2,436.1 $\mathrm{mm}$ and evapotranpiration 1,230.4 $\mathrm{mm}$ or $3.4 \mathrm{~mm} /$ day.

Paharangan area has B climate type with $Q$ value $=32.4 \%$ or this area is wet with still tropical rainforest according to Schmidth - Ferguson (1951) classification and has C2 climate type according to Oldeman (1980) classification system or in one year this area can cultivate paddy one time and crops planted as $2 \mathrm{~d}$ crop in dry season must be planted carefully. The annual rainfall is about 2,311.8 $\mathrm{mm}$ and evapotranpiration 1,230.4 $\mathrm{mm}$ or $3.4 \mathrm{~mm} /$ day.

\begin{tabular}{|c|c|c|c|c|c|c|c|c|c|}
\hline \multirow{3}{*}{ Month } & \multicolumn{9}{|c|}{ Climatic Element } \\
\hline & \multirow{2}{*}{$\begin{array}{c}\text { Rainfall } \\
(\mathrm{mm})\end{array}$} & \multirow{2}{*}{$\begin{array}{l}\text { Rain } \\
\text { Day }\end{array}$} & \multirow{2}{*}{$\begin{array}{c}\text { Atmospheric } \\
\text { Pressure }\end{array}$} & \multirow{2}{*}{$\begin{array}{c}\begin{array}{c}\text { Relative } \\
\text { Humidity }\end{array} \\
(\%)\end{array}$} & \multirow{2}{*}{$\begin{array}{c}\begin{array}{c}\text { Air } \\
\text { Temperature }\end{array} \\
\left({ }^{\circ} \mathrm{C}\right)\end{array}$} & \multirow{2}{*}{$\begin{array}{c}\text { Evapotran } \\
\text { piration, } \\
\text { ETo }_{0} \\
(\mathrm{~mm})^{2)}\end{array}$} & \multicolumn{2}{|c|}{$\begin{array}{l}\text { Wind Velocity } \\
\text { and Direction }\end{array}$} & \multirow{2}{*}{$\begin{array}{c}\text { Time of } \\
\text { Sunshine } \\
(\%)\end{array}$} \\
\hline & & & & & & & (knot) & o 1) & \\
\hline January & 300,8 & 16,3 & 1006,9 & 90,5 & 26,4 & 111,0 & 1,3 & $\mathrm{BL}$ & 42,8 \\
\hline February & 224,9 & 14,6 & 1006,3 & 90,9 & 26,9 & 98,3 & 2,0 & $\mathrm{BL}$ & 36,4 \\
\hline March & 298,6 & 16,1 & 1006,5 & 87,0 & 27,7 & 115,6 & 2,1 & $\mathrm{BL}$ & 37,4 \\
\hline April & 238,1 & 15,9 & 1006,2 & 90,1 & 28,8 & 111,0 & 3,6 & $\mathrm{BL}$ & 41,0 \\
\hline May & 178,7 & 10,9 & 1006,0 & 90,1 & 27,8 & 120,9 & 2,5 & BBD & 57,0 \\
\hline June & 181,0 & 11,1 & 1007,1 & 84,6 & 27,9 & 104,7 & 1,4 & BBD & 53,4 \\
\hline
\end{tabular}

Table 1. Climatic Elements in Tabalong Regency 
Rusmayadi, G and Khairina, R : Productivity of Hairy Water lily (Nhymphaea pubescens Will.)

\begin{tabular}{|c|c|c|c|c|c|c|c|c|c|}
\hline July & 98,0 & 7,9 & 1007,0 & 90,4 & 27,2 & 120,0 & 2,3 & $\mathrm{BD}$ & 62,1 \\
\hline August & 102,9 & 7,6 & 1007,8 & 90,5 & 27,3 & 128,0 & 2,3 & $S$ & 61,4 \\
\hline September & 129,3 & 8,9 & 1007,3 & 89,5 & 28,5 & 122,4 & 1,9 & SBD & 50,9 \\
\hline October & 148,8 & 11,7 & 1006,9 & 90,6 & 27,5 & 122,1 & 1,7 & SBD & 49,2 \\
\hline November & 298,2 & 14,6 & 1006,2 & 90,6 & 26,8 & 98,7 & 2,1 & BBD & 35,7 \\
\hline December & 379,9 & 20,6 & 1006,0 & 91,9 & 27,5 & 101,7 & 4,2 & BBD & 33,5 \\
\hline Total & 2579,1 & 156 & & & & 1354,4 & & & \\
\hline Average & & & 1006,7 & 89,7 & 27,5 & & 2,3 & & 46,7 \\
\hline STD (\%) & 9,75 & 3,39 & 0,18 & 0,00 & 0,00 & & 0,00 & & 0,00 \\
\hline Source: & $\begin{array}{l}\text { Data is } \\
\text { 1) BMKC } \\
\text { 2) Data i }\end{array}$ & $\begin{array}{l}\text { culate } \\
\text { anjarb } \\
\text { stimat }\end{array}$ & $\begin{array}{l}\text { Taba } \\
\text { tation } \\
\text { cordin }\end{array}$ & $\begin{array}{l}\text { Figures } \\
\text { 2007) } \\
\text { lan-Mo }\end{array}$ & -2011) & & & & \\
\hline
\end{tabular}

Table 2. Climatic Elements in Hulu Sungai Utara Regency

\begin{tabular}{|c|c|c|c|c|c|c|c|c|c|}
\hline \multirow{3}{*}{ Month } & \multicolumn{9}{|c|}{ Climatic } \\
\hline & Rainfall & $\begin{array}{l}\text { day of } \\
\text { rain }\end{array}$ & $\begin{array}{c}\text { Air } \\
\text { Pressure }\end{array}$ & Air Moisture & $\begin{array}{c}\text { Air } \\
\text { Temperature }\end{array}$ & $\begin{array}{l}\text { Evapotran } \\
\text { spiration }\end{array}$ & Wi & & $\begin{array}{l}\text { Length of } \\
\text { sunshine }\end{array}$ \\
\hline & $(\mathrm{mm})$ & (hh) & $(m b)^{1)}$ & $(\%)$ & $\left.{ }^{\circ} \mathrm{C}\right)$ & $(\mathrm{mm}) 2$ & (knot) & 0 11) & (\%) \\
\hline January & 295,0 & 18,8 & 1009,9 & 87,8 & 26,0 & 105,9 & 4,3 & $B$ & 39,6 \\
\hline February & 276,2 & 16,1 & 1010,1 & 87,4 & 26,1 & 96,2 & 3,8 & $\mathrm{BD}$ & 37,3 \\
\hline Mart & 326,0 & 18,9 & 1009,9 & 88,3 & 26,3 & 112,0 & 3,7 & $\mathrm{BD}$ & 43,9 \\
\hline April & 262,7 & 16,0 & 1009,7 & 88,6 & 26,4 & 113,6 & 3,8 & $\mathrm{BL}$ & 56,2 \\
\hline May & 168,8 & 11,4 & 1009,9 & 88,4 & 26,8 & 110,1 & 4,1 & $\mathrm{TL}$ & 55,0 \\
\hline June & 96,5 & 8,7 & 1010,3 & 86,4 & 26,6 & 106,6 & 3,8 & $T$ & 59,4 \\
\hline July & 62,3 & 8,3 & 1010,8 & 86,1 & 26,7 & 113,3 & 3,8 & $T$ & 59,8 \\
\hline August & 53,8 & 5,9 & 1011,1 & 84,5 & 27,0 & 127,5 & 4,4 & $T$ & 64,3 \\
\hline September & 69,3 & 8,9 & 1010,8 & 85,2 & 27,1 & 116,6 & 4,7 & $\mathrm{Tg}$ & 50,4 \\
\hline October & 189,1 & 12,6 & 1010,5 & 85,9 & 26,6 & 123,6 & 4,2 & $\mathrm{Tg}$ & 53,8 \\
\hline November & 257,2 & 18,4 & 1009,8 & 88,2 & 26,1 & 106,1 & 4,2 & $B$ & 44,6 \\
\hline December & 379,3 & 22,3 & 1010,1 & 88,2 & 25,9 & 98,8 & 4,0 & $B$ & 33,9 \\
\hline Total & 2436,1 & 166 & & & & 1330 & & & \\
\hline Average & & & 1010,3 & 87,1 & 26,5 & & 4,1 & & 49,8 \\
\hline STD & 5,7 & 5,7 & 100,0 & 0,6 & 0,1 & & 0,0 & & 9,3 \\
\hline
\end{tabular}

Table 3. Climatic Elements in Hulu Sungai Selatan Regency

\begin{tabular}{|c|c|c|c|c|c|c|c|c|c|}
\hline \multirow{3}{*}{ Month } & \multicolumn{9}{|c|}{ Climatic Element } \\
\hline & Rainfall & $\begin{array}{l}\text { Rain } \\
\text { Day }\end{array}$ & $\begin{array}{l}\text { Atmospheri } \\
\text { c Pressure }\end{array}$ & $\begin{array}{l}\text { Relative } \\
\text { Humidity }\end{array}$ & $\begin{array}{c}\text { Air } \\
\text { Temperatur } \\
\text { e }\end{array}$ & $\begin{array}{l}\text { Evapotra } \\
\text { npiration, }\end{array}$ & $\begin{array}{l}\text { Wind } \\
\text { and } D\end{array}$ & $\begin{array}{l}\text { ocity } \\
\text { ction }\end{array}$ & $\begin{array}{l}\text { Time of } \\
\text { Sunshine }\end{array}$ \\
\hline & $(\mathrm{mm})$ & (hh) & $(m b)^{11}$ & $(\%)$ & $\left({ }^{\circ} \mathrm{C}\right)$ & & (knot) & o 1) & $(\%)$ \\
\hline January & 295,0 & 18,8 & 1009,9 & 87,8 & 26,0 & 105,9 & 4,3 & $\mathrm{~B}$ & 39,6 \\
\hline February & 276,2 & 16,1 & 1010,1 & 87,4 & 26,1 & 96,2 & 3,8 & $\mathrm{BD}$ & 37,3 \\
\hline Mart & 326,0 & 18,9 & 1009,9 & 88,3 & 26,3 & 112,0 & 3,7 & $\mathrm{BD}$ & 43,9 \\
\hline April & 262,7 & 16,0 & 1009,7 & 88,6 & 26,4 & 113,6 & 3,8 & $\mathrm{BL}$ & 56,2 \\
\hline May & 168,8 & 11,4 & 1009,9 & 88,4 & 26,8 & 110,1 & 4,1 & $\mathrm{TL}$ & 55,0 \\
\hline June & 96,5 & 8,7 & 1010,3 & 86,4 & 26,6 & 106,6 & 3,8 & $T$ & 59,4 \\
\hline July & 62,3 & 8,3 & 1010,8 & 86,1 & 26,7 & 113,3 & 3,8 & $T$ & 59,8 \\
\hline August & 53,8 & 5,9 & 1011,1 & 84,5 & 27,0 & 127,5 & 4,4 & $T$ & 64,3 \\
\hline September & 69,3 & 8,9 & 1010,8 & 85,2 & 27,1 & 116,6 & 4,7 & $\mathrm{Tg}$ & 50,4 \\
\hline October & 189,1 & 12,6 & 1010,5 & 85,9 & 26,6 & 123,6 & 4,2 & $\mathrm{Tg}$ & 53,8 \\
\hline November & 257,2 & 18,4 & 1009,8 & 88,2 & 26,1 & 106,1 & 4,2 & $B$ & 44,6 \\
\hline December & 379,3 & 22,3 & 1010,1 & 88,2 & 25,9 & 98,8 & 4,0 & $B$ & 33,9 \\
\hline Total & 2436,1 & 166 & & & & 1330 & & & \\
\hline Average & & & 1010,3 & 87,1 & 26,5 & & 4,1 & & 49,8 \\
\hline STD & 5,7 & 5,7 & 100,0 & 0,6 & 0,1 & 0,0 & 0,0 & & 9,3 \\
\hline Source: & Data & SII & $\begin{array}{l}\text { PHTPH } \\
\text { Station }\end{array}$ & $\begin{array}{l}\text { t Manac } \\
2007)\end{array}$ & it Control) & Rive & $\operatorname{Res}$ & & \\
\hline
\end{tabular}

\subsection{Water Level}

The water level at the study area was relative the same in April. The highest water level was more than $100 \mathrm{~cm}$ at Paharangan subdistrict and the lowest about $80 \mathrm{~cm}$ at Hambuku subdistrict. After May, water begins to subside, so the hairy water lily seeds can 
be harvested and the preparation for paddy field can be started (Figure 1).

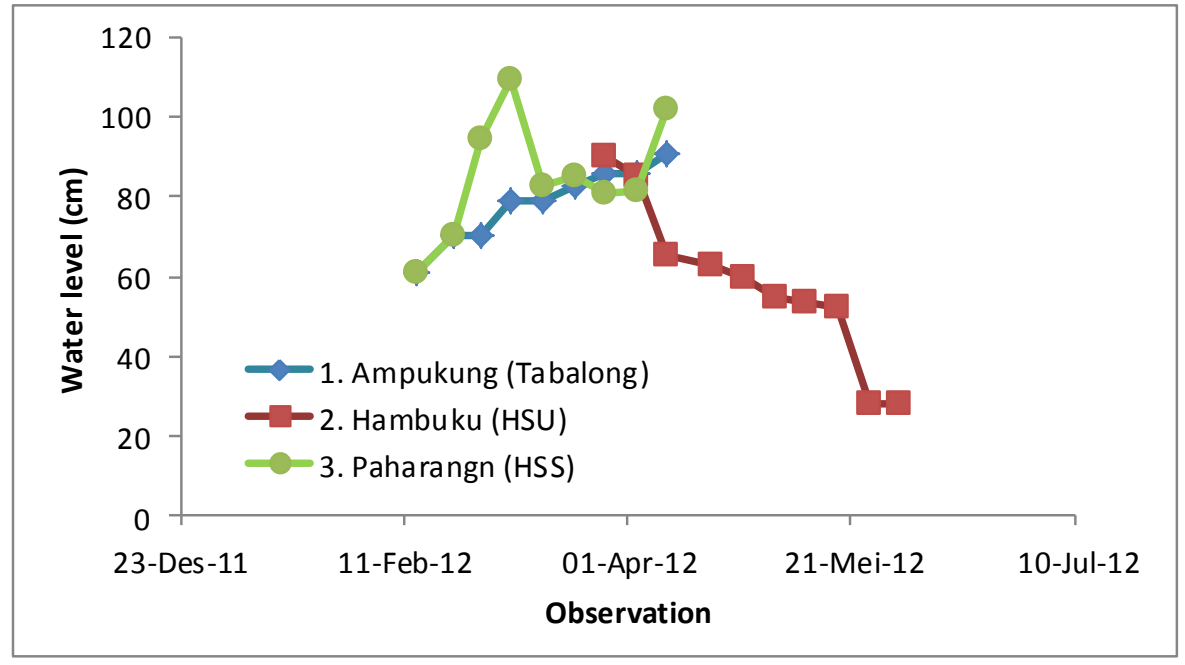

Figure 1. Water level fluctuation in study area

\subsection{Growth of Hairy Water Lily Seeds}

The hairy water lily seeds were about $0.9-1.3 \mathrm{t} / \mathrm{ha}$. The highest yield was at Ampukung subdistrict because the temperature at Ampukung (about $27.5^{\circ} \mathrm{C}$ ) was higher than the other areas, and the lowest yield was at Paharangan subdistrict. The higher temperature can make hairy water lily's evapotranspiration higher. The higher evapotranspiration can make photosynthesis better.
The highest yield is not determined by water level Table 1). It estimated that the high water level increased the vegetative growth. In Hambuku, Ampukung, and Paharangan subdistricts, the water level was $57.9 \mathrm{~cm}, 78.2 \mathrm{~cm}$, and $85.3 \mathrm{~cm}$, respectively, while the respective crop length was 73.4 $\mathrm{cm}, 85.8 \mathrm{~cm}$, and $109.4 \mathrm{~cm}$. This indicates that the highest water level can make plants grow taller.

Table 1. Water level, Growth and Yield

\begin{tabular}{|c|c|c|c|c|c|c|c|c|}
\hline \multirow[b]{2}{*}{ No } & \multirow[b]{2}{*}{ Parameter } & \multirow[b]{2}{*}{ Unit } & \multicolumn{5}{|c|}{ Area Study } & \multirow[b]{2}{*}{ SE } \\
\hline & & & $\begin{array}{l}\text { Ampukung } \\
\text { (Tabalong) }\end{array}$ & SE & $\begin{array}{l}\text { Hambuku } \\
\text { (HSU) }\end{array}$ & SE & $\begin{array}{l}\text { Paharang } \\
\text { an (HSS) }\end{array}$ & \\
\hline 1 & Water level & $\mathrm{cm}$ & 78,18 & 0,81 & 57,94 & 0,07 & 85,28 & 0,24 \\
\hline 2 & Plant hight per cluster & $\mathrm{cm}$ & 85,79 & 0,81 & 73,37 & 0,06 & 109,41 & 0,24 \\
\hline 3 & Total leaf per cluster & helai & 2,44 & 0,04 & 18,27 & 0,09 & 19,50 & 0,24 \\
\hline 4 & Total flowers per cluster & buah & 2,28 & 0,04 & 1,00 & 0,00 & 2,38 & 0,24 \\
\hline 5 & Total fruit per cluster & buah & 2,13 & 0,04 & 2,84 & 0,03 & 1,81 & 0,24 \\
\hline 6 & Total harvested fruit per cluster & buah & 0,83 & 0,01 & 2,00 & 0,00 & 0,91 & 0,24 \\
\hline 7 & Harvested fruit weight per cluster & $\mathrm{g}$ & 213,61 & 5,24 & 252,00 & 2,87 & 307,14 & 0,24 \\
\hline 8 & Dry fruit weight per plant & $g$ & 25,63 & 0,45 & 22,03 & 0,18 & 18,28 & 0,24 \\
\hline 9 & Dry fruit weight per $\mathrm{m}^{2}$ & $g$ & 128,13 & 2,27 & 110,17 & 0,89 & 91,42 & 0,24 \\
\hline 10 & Dry fruit weight per hektare & $\mathrm{t}$ & 1,28 & \#REF! & 1,10 & 0,00 & 0,91 & 0,24 \\
\hline 11 & Dry fruit weight per hektare (Model) & $\mathrm{t}$ & 1,12 & 0,00 & 1,06 & 0,00 & 0,65 & 0,00 \\
\hline
\end{tabular}

\subsection{Estimation of Hairy water lily's yield} based on linear Model

\subsubsection{Hairy water lily's yield based on field} observation

Based on the field observation, the hairy water lily seeds harvested in Ampukung, Hambuku and Paharangan were $1.121 \mathrm{t}, 1.057 \mathrm{t}$ and $0.653 \mathrm{t}$, respectively. The potential paddy fields that can be cultivated for hairy water lily in Tabalong, HSU and HST regencies were about 10,683 ha, 21,2252 ha, and 18,763 ha, respectively. It shows that each zone has the potential to produce about 11,976.661 t/ha, 224,456.2 t/ha and 12,254.6778 t/ha. 
Rusmayadi, G and Khairina, R : Productivity of Hairy Water lily (Nhymphaea pubescens Will.)

1.4.2. Hairy water lily's yield based on linear model (Agroecological Zone, AEZ)

Table 2. Based on radiation $\left(R_{g}\right)$, photosyntetically active radiation on very clear days $\left(A_{c}\right)$, in cal $\mathrm{cm}^{-2}$ day ${ }^{-1}$, and daily gross photosynthesis rate of crop canopies on very clear days $\left(b_{c}\right)$ in $\mathrm{kg} \mathrm{ha}^{-1}$ day-1 fot $\mathrm{Pm}=20 \mathrm{~kg} \mathrm{CH}_{2} \mathrm{O} \mathrm{ha} \mathrm{hr}^{-1}$, so the yield of

Table 2. Estimation of Yield Biomass Parameter

Paharangan subdistrict

\begin{tabular}{lccccccccc}
\hline \multirow{2}{*}{ Bulan } & $\mathrm{Rg}$ & \multicolumn{1}{c}{$\mathrm{Ac}$} & $\mathrm{bc}$ & bo & $\mathrm{Tr}$ & Tmak & Tmin & Tsh & $\mathrm{N}$ \\
\cline { 2 - 11 } & \multicolumn{7}{c}{$\mathrm{cal} / \mathrm{cm}^{2} / \mathrm{day}$} & & \multicolumn{2}{c}{${ }^{\circ} \mathrm{C}$} & & \\
\hline Januari & 312 & 347,95 & 417,25 & 221,4 & 27,45 & 30,8 & 24,1 & 29,2 & 12,1 \\
\hline Februri & 354 & 360,4 & 424,55 & 226,7 & 27,65 & 31,25 & 24,05 & 29,7 & 12,1 \\
\hline Maret & 344 & 368 & 429 & 230 & 27,5 & 31 & 24 & 30,6 & 12,1 \\
\hline Rata-rata & 336,7 & 358,8 & 423,6 & 226,0 & 27,5 & 31,0 & 23,7 & 29,8 & 12,1 \\
\hline
\end{tabular}

Hambuku subdistrict

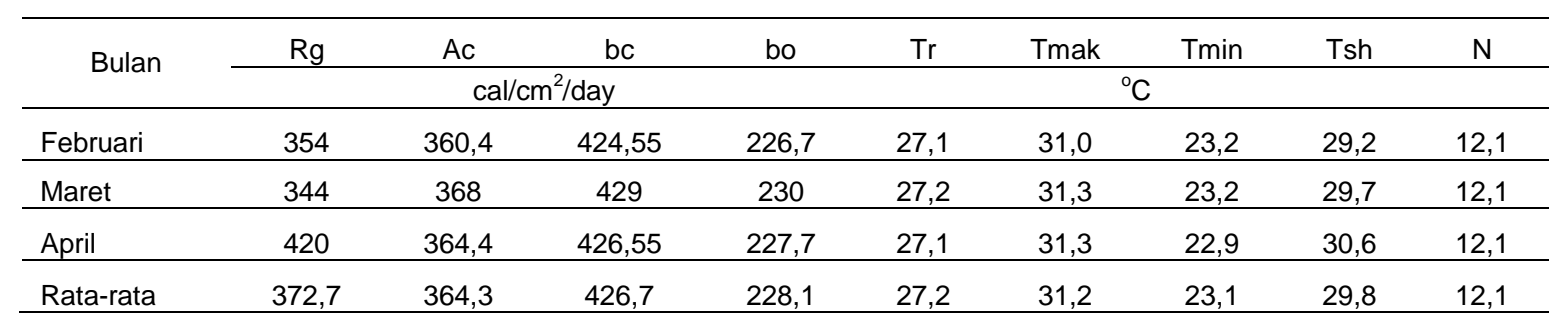

Ampukung subdistrict

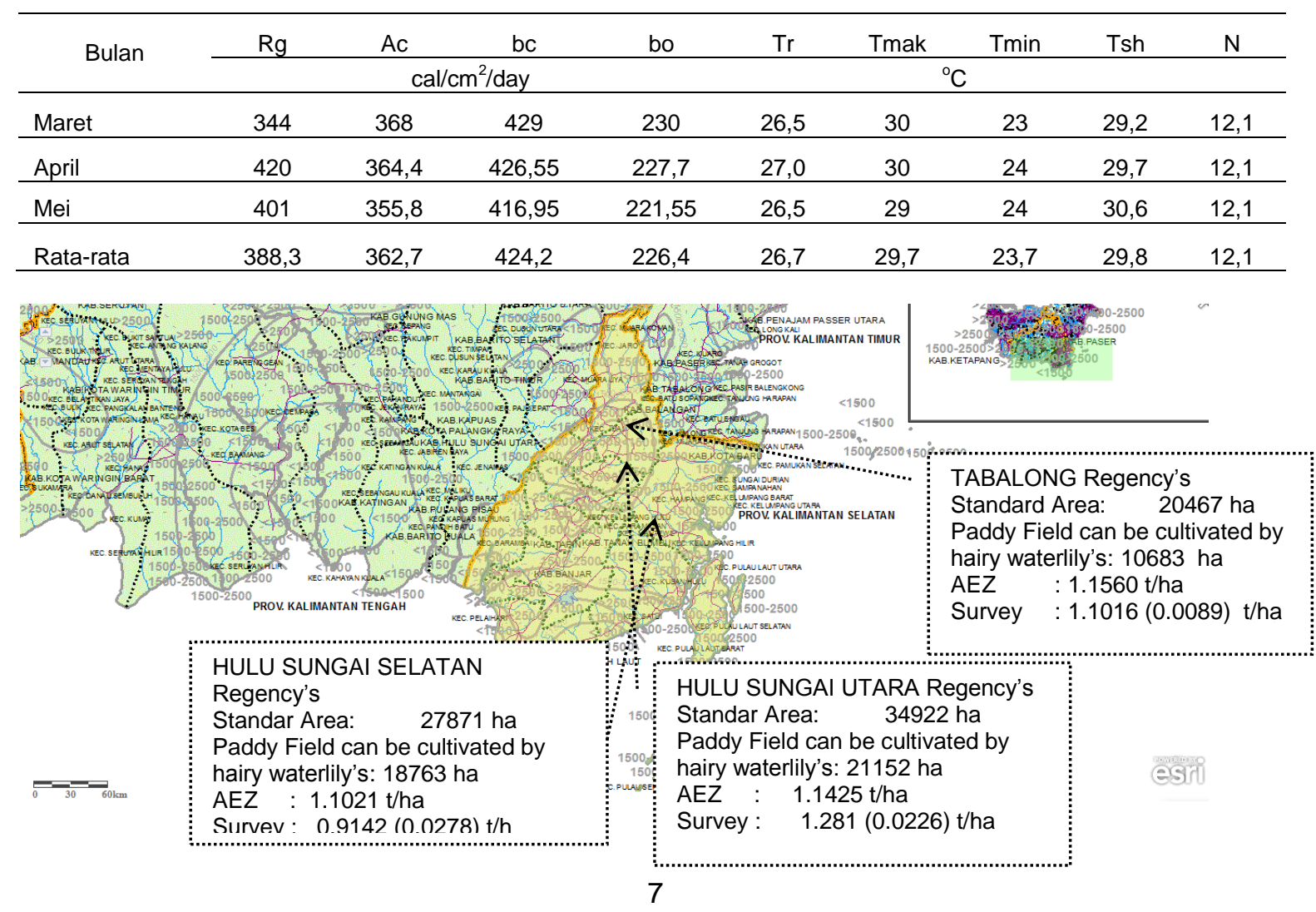


Figure 2. Hairy water lily's yield based on AEZ model and observation in Ampukung, Hambuku and Paharangan subdistricts.

The validation between $A E Z$ model and observation data shows no significant difference. It means that the model linier of AEZ can be used to predict hairy water lily's yield. The area with highest radiation has highest yield.

\section{CONCLUSION}

Vegetative growth of hairy water lily is determined by the water level. If the vegetative growth is higher than the generative, the seeds could be less. The linear model of agroecologycal zone predicts the yield based on radiation. The model predicted that the maximum yield was in the area having highest radiation; therefore, Ampukung subdistrict had the highest yield, followed by Hambuku and Paharangan.The hairy water lily's growth is naturally with rhizomes in the soil of paddy field. If the water level is high, the hairy water lily can grow, develop, and yield. Therefore, the agronomy of hairy water lily should be investigated to increase its productivity.

\section{REFERENCES}

Statistics (BPS) of Hulu Sungai Utara, 2010. Hulu Sungai Utara in Figures. Statistics of Hulu Sungai Utara. Amuntai. $400 \mathrm{p}$.

Doorenbos, J \& Kassam, AA. 1986. Yield Response to Water. FAO Irrigation and Drainage Paper. No. 33. Rome. 193 p.

FAO. 1979. Yield Response to Water. FAO Irrigation and drainage paper, via delle Terme di Caracalla 00100 Rome, Italy.

Fuaddi, K. 1996. Analysis of Nutrient Content in Tubers, Fruit Seeds and Stems of Hairy Water Lily (Nymphae pubescens Wild). [Thesis]. Banjarmasin: Faculty of Teacher Training and Education, Lambung Mangkurat University.

Khairina, R \& Fitrial Y. 2002. Production and Nutrient Content of Hairy Water Lily (Nymphaea pubescens Wild) Seeds, the Water Plant in Hulu Sungai Utara Regency. Scientific Journal of Agricultural Faculty
Lambung Mangkurat University, 2(9) :77-88.

Sastrapraja \& Bimantoro. 1981. Water Plants. National Biological Institute, LIPI. Bogor.

Stodolo J. 1987. Aquarium Plants. T.F.H. Publications. Inc. 